\title{
Erratum to "How Indian CPI and Industrial Production Respond to Global Oil Price Shocks? Regime-Dependent Impulse Responses" [Theoretical Economics Letters 7 (2017) 1511-1531]
}

\author{
Amanjot Singh, Rajdeep Singh \\ Punjabi University, Patiala, India \\ Email: amanjot_42@yahoo.com
}

Received: July 23, 2017

Accepted: August 19, 2017

Published: August 22, 2017

Copyright ( 2017 by authors and Scientific Research Publishing Inc.

This work is licensed under the Creative

Commons Attribution International

License (CC BY 4.0).

http://creativecommons.org/licenses/by/4.0/
The original online version of this article (Singh, A. and Singh, R. (2017) How Indian CPI and Industrial Production Respond to Global Oil Price Shocks? Regime-Dependent Impulse Responses. Theoretical Economics Letters, 7, 1511-1531. https://doi.org/10.4236/tel.2017.75102) was published without referring the source of Figure 1. The same is provided as follows:

Raminagrobis (2016) India (Oil).

https://commons.m.wikimedia.org/wiki/File:Oil_Balance_India.svg\#mw-jump-t o-license

https://en.m.wikipedia.org/wiki/Energy_policy_of_India\#/media/File\%3AOil_B alance_India.svg 